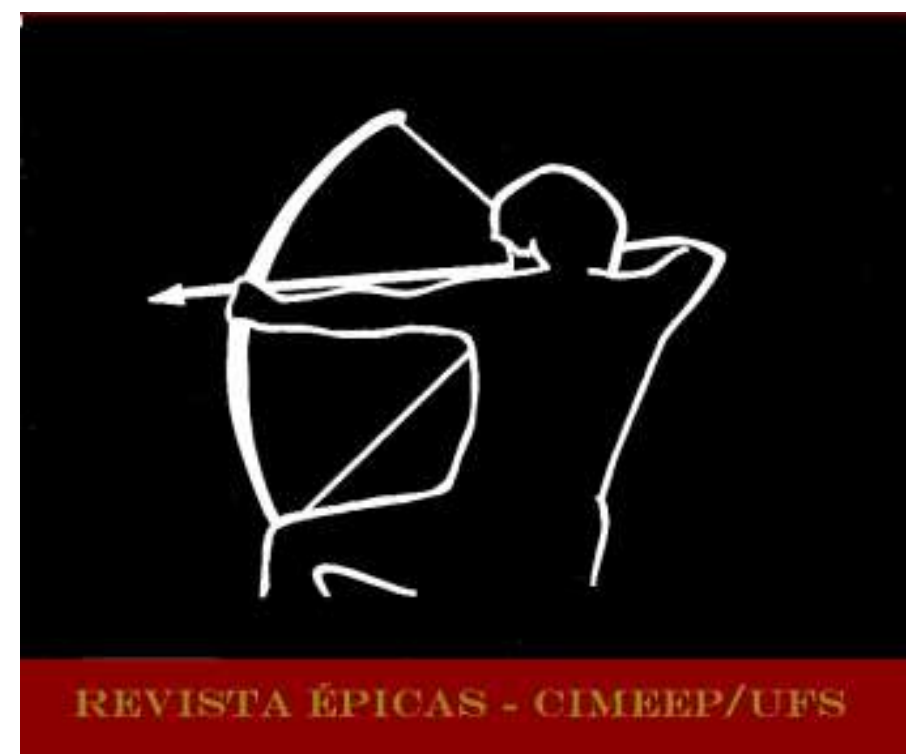

GARNCARZYK, Dimitri. "A maior obra de que a natureza humana é capaz". O que é uma epopeia no século XVIII? Trad. Christina Ramalho, Margarida Maria Araujo Bispo e Marie Madeleine Dupon. In: Revista Épicas. Ano 4, N. 7, Jun 2020, p. 1-29. ISSN 2527-080-X.

\title{
"A MAIOR OBRA DE QUE A NATUREZA HUMANA É CAPAZ"1. O QUE É UMA EPOPEIA NO SÉCULO XVIII?
}

\section{"LE PLUS GRAND OUVRAGE DONT LA NATURE HUMAINE SOIT CAPABLE". QU'EST-CE QU'UNE ÉPOPÉE AU $18^{\mathrm{e}}$ SIÈCLE?"2}

\author{
Dimitri Garncarzyk ${ }^{3}$ \\ CERC, Sorbonne Nouvelle
}

\footnotetext{
${ }^{1}$ Artigo publicado na Le Recueil Ouvert, com título original: "Le plus grand ouvrage dont la nature humaine soit capable". Qu'est-ce qu'une épopée au $18^{e}$ siècle ?". Referência original completa: GARNCARZYK, Dimitri , "Le plus grand ouvrage dont la nature humaine soit capable". Qu'est-ce qu'une épopée au $18^{\mathrm{e}}$ siècle ?», Le Recueil Ouvert [En ligne], mis à jour le : 11/10/2017, URL : http://ouvroir-litt-arts.univ-grenoble-alpes.fr/revues/projet-epopee/277--leplus-grand-ouvrage-dont-la-nature-humaine-soit-capable-qu-est-ce-qu-une-epopee-au-18e-siecle.

2 Margarida Maria Araújo é professora de Língua Portuguesa, Redação e Literatura nas redes: Estadual de Sergipe e Municipal de Tobias Barreto, Sergipe. Mestra em Literatura e Recepção pela Universidade Federal de Sergipe/UFS, Graduada em Letras/Português pela UFS e pós-graduada em Planejamento Educacional pela Universidade Salgado de Oliveira. Irmã Marie Madeleine Dupon é enfermeira graduada pelo "Institut de Nursing Sainte Elisabeth", Namur, Bélgica.

3 Dados informados na versão original em francês (2017): Dimitri Garncarzyk é professor associado de literatura moderna, formado em inglês e mestre em pesquisa em Literatura Comparada. Vencedor do prêmio do século XVIII pelo SFEDS (2013) e uma bolsa Thiers (2017-2018), atualmente está concluindo a redação de uma tese de doutorado em Literatura Geral e Comparada (CERC, Sorbonne Nouvelle) sobre o gênero épico na Europa do lluminismo, da Inglaterra à Polônia e Sérvia. Seu trabalho se concentra principalmente na produção e teoria da epopeia na Europa moderna, especialmente na Europa Central ("Est-il "si aisé" d'améliorer la Henriade ? Petit traité de "misologie"”, atelier de théorie littéraire du site Fabula : http://www.fabula.org/atelier.php?Misologie, 2010 ; "Ce feu brûlant de la poésie que le génie seul peut allumer" : sur une traduction de la Myséide aujourd'hui perdue, et une autre par le poète lui-même, mais inachevée. In : Yen-Mai Tran-Gervat (Dir.). Traduire en français à l'âge classique. Paris : Presses Sorbonne Nouvelle, 2013, p. 195-210).
} 
RESUMO: O status da epopeia produzida no século XVIII em muitos países europeus (principalmente na França, Inglaterra ou Polônia) foi amplamente determinada por uma relação com os textos abrangidos pela poética clássica, que por sua vez pode ser definida como a combinação de uma perspectiva prospectiva da literatura (isto é, o planejamento de epopeias ainda a serem escritas) associada a uma interiorização dos textos do passado (a crítica das epopeias antigas e modernas). O presente estudo discute as diferenças metodológicas existentes entre as poéticas do século XVIII que operam nesse enquadramento teórico: se todos concordam que sua função é articular a recepção do patrimônio e da criação contemporânea, eles fazem isso de diferentes maneiras para definir a epopeia que permanece como "a maior obra de que a natureza humana é capaz".

Palavras-chave: Teoria épica; Século XVIII; Epopeias antigas; Epopeias modernas.

RESUME : Le statut de l'épopée dans une partie de l'Europe du $18^{\mathrm{e}}$ siècle (en France, en Angleterre, en Pologne) est largement déterminé par un rapport aux textes qui relève de la poétique classique, laquelle peut être définie comme une prospection des possibles de l'écriture (la planification d'épopées à venir) associée à une intériorisation des textes du pass (la critique des épopées antiques et modernes). Cette étude s'intéresse aux différences méthodologiques qui existent entre différents poéticiens du $18^{\mathrm{e}}$ siècle qui opèrent dans ce cadre théorique : si tous s'accordent à considérer que leur fonction est d'articuler la réception du patrimoine et la création contemporaine, ils s'y prennent de différentes manières pour définir l'épopée qui reste alors "le plus grand ouvrage dont la nature humaine soit capable".

Mots-clés : Théorie épique; XVIII siècle; Épopées anciennes; Épopées modernes.

Introdução. Em que se fala de uma tese em andamento sobre a epopeia, o classicismo na Europa e H. R. Jauss

\section{Uma tese: Teorias e práticas da epopeia de Boileau a Ignacy Krasicki}

Na origem da tese que estamos prestes a concluir, intitulada Théories et pratiques de l'épopée de Boileau à Ignacy Krasicki [Teorias e práticas da epopeia de Boileau a Ignacy Krasicki] (registrada desde $2012^{4}$ ), encontramos uma teoria e um evento.

A teoria é a de textos possíveis. Iniciada por Michel Charles em L'Arbre et la source ${ }^{5}$ A Árvore e a fonte] e Introduction à l'étude des textes [Introdução ao estudo de textos], teve continuidade em particular sob o impulso de Marc Escola e Sophie Rabau ${ }^{6}$, e consiste em considerar a teoria literária como a invenção das práticas de escrita: uma perspectiva que visa esboçar possibilidades futuras de escrita ${ }^{7}$. Na obra de Michel Charles, essa atitude não é não apenas teórica, mas se incorpora na história, sendo, segundo esse crítico, característica do "sistema clássico" (mais ou menos o do mundo literário francês do século XVII) constituído na

\footnotetext{
${ }^{4}$ Em: http://www.theses.fr/s79646.

${ }^{5}$ CHARLES, Michel. L’Arbre et la Source. Paris : Seuil, “Poétique”,1985 ; Introduction à l'étude des textes, Paris : Seuil, "Poétique.", 1995

${ }^{6}$ Notadamente em ESCOLA, Marc; RABAU, Sophie (Dir.). Théorie littéraire et textes possibles. La Lecture littéraire. Paris : Klincksieck, 2005, e ESCOLA, Marc (Dir.). Théorie des textes possibles. Amsterdam: Rodopi, 2012.

${ }^{7}$ Ver a introdução de ESCOLA, Marc; RABAU, Sophie (Dir.). Théorie littéraire et textes possibles, op. cit., p. 9 sqq. : "Inventer la pratique".
} 
"cultura retórica", ou seja, "une culture où la lecture est tournée vers une écriture" [uma cultura na qual a leitura é voltada para a escrita] ${ }^{8 \prime}$.

O evento é a querela de Homero que opôs, na ocasião da publicação de sua tradução da llíada de Homero, na década de 1710, a erudita Anne Dacier e o acadêmico Antoine Houdar de La Motte. O acadêmico "retraduziu" a llíada, não do grego (que ele prontamente admitiu ignorar ${ }^{9}$ ), mas do texto francês de Anne Dacier. Enquanto a erudita traduziu a prosa para seguir melhor o estilo de Homero, La Motte restabeleceu o alexandrino, sem o qual não se podia falar de um poema épico; enquanto Anne Dacier fez um trabalho volumoso contendo os vinte e quatro cantos da llíada acompanhados de "Notas" filológicas, a versão de La Motte, desprovida de paratexto, reduziu o poema para doze cantos. Em suma, enquanto Anne Dacier traduziu a llíada de Homero, com comentários, La Motte compôs L'lliade, poème français ${ }^{10}$.

Em torno da herança homérica, assim, confrontados, no início do segundo dos "séculos clássicos", dois textos possíveis ${ }^{11}$, cada um propondo uma definição singular da relação entre a antiga herança literária e a criação literária moderna. O episódio da querela de Homero mostra claramente a que ponto a prospectiva que constitui a reflexão poética da "era retórica" está ligada a uma retrospectiva histórica e cultural: explorar a possibilidade da escritura é avaliar o valor de uma herança. As paixões envolvidas na querela são proporcionais à importância do gênero, porque a epopeia é o gênero supremo (da poesia narrativa em Aristóteles e, depois das poéticas do Renascimento, a poesia apenas ${ }^{12}$ ).

O evento da querela de Homero, portanto, constitui uma crise na teoria dos textos possíveis - que coincide com o que Paul Hazard chamou de "la crise de la conscience européenne" [a crise da consciência europeia] ${ }^{13}$. Daí duas perguntas às quais nossa tese pretende responder: por um lado, esse tipo de debate excede as fronteiras da França e, por outro lado, quais valores (literários, e mais amplamente intelectuais e sociais) o debate sobre o gênero épico colocou em cena no século XVIII?

A resposta (afirmativa) à primeira questão é bastante fácil e marca o ponto de partida para a constituição de um corpus europeu de textos teóricos (de poética) sobre o gênero épico,

\footnotetext{
${ }^{8}$ CHARLES, Michel, L'Arbre et la Source, op. cit., p. 185. N.T. Procuramos manter as citações do autor em sua forma original.

${ }^{9}$ Ver o capítulo consagrado a sua incompetência linguística no pedido de desculpas de sua abordagem: HOUDAR DE LA MOTTE, Antoine. Réflexions sur la critique. Paris : Du Puis, 1715, [1ère partie], "De l'ignorance du grec", p. 56 sqq. 10 Estes são os títulos das primeiras edições: L'lliade d'Homère, traduite en françois, avec des remarques, par Madame Dacier. Paris : Rigaud, 1711, 3 vol. ; L'lliade. Poëme. Avec un discours sur Homère. Par Monsieur de la Motte, de l'Académie Françoise. Paris: Grégoire Dupuis, 1714, 1 vol.

${ }^{11}$ Mantivemos os registros em itálico presentes no texto original.

12 La Renaissance $a$, de fait, retiré à la tragédie la prééminence que lui conférait Aristote pour mettre l'épopée à sa place. Ver, por exemplo, SCALIGER, Julius Cæsar. Poetices libri VII, [Genève], apud Petrum Santandreanum, 1594, p. 14 : "Epicum, quod idcirco omnium est princeps, quia continet materias universas".

${ }^{13}$ HAZARD, Paul. La Crise de la conscience européenne [1935]. Paris: Le livre de Poche,1994.
} 
mas também, já que a poética é tão prospectiva de textos que virão como apropriação de textos do passado, de poemas épicos do século XVIII. Deixaremos a segunda em suspenso no momento, mas delinearemos, na conclusão deste estudo, uma resposta inicial.

\subsection{Um corpus: poetas e poéticas clássicas}

A ideia, apresentada como "clássica" por Michel Charles, de uma poética prospectiva fundada na retomada da herança antiga, ainda é amplamente difundida na Europa do século XVIII - na França, evidentemente, mas também na Inglaterra por Pope, Addison e Johnson, ou na Polônia, na segunda metade do século, onde o classicismo stanislaviano (Klasycyzm Stanisławowski) se desenvolveu a partir da leitura de críticos franceses e ingleses.

De fato épico, o texto fundador é sem dúvida o Traité du poème épique [Tratado do poema épico] (1675) do padre René Le Bossu. A influência desse texto ainda era perceptível em 1728, quando um tratado poético intitulado Peri Bathous apareceu na Inglaterra, devido a um certo Martin Scriblerus. O capítulo 15 deste tratado é intitulado "A Receipt to make an Epic Poem" [Receita para compor um poema épico] e começa da seguinte forma:

An epic poem, the critics agree, is the greatest work human nature is capable of. They have already laid down many mechanical rules for compositions of this sort, but at the same time they cut almost off almost all undertakers from the possibility of ever performing them ; for the first qualification they unanimously require in a poet, is a genius. I shall here endeavour (for the benefit of my countrymen) to make it manifest, that epic poems may be made without a genius, nay without learning or much reading. This must necessarily be of great use to all those who confess they never read, and of whom the world is convinced they never learn ${ }^{14}$.

[Um poema épico, concordam os críticos, é a maior obra de que a natureza humana é capaz. Eles já estabeleceram muitas regras mecânicas para composições desse tipo, mas, ao mesmo tempo, eliminam quase todos os empreendedores da possibilidade de executá-las; pois a primeira qualificação exigida por unanimidade em um poeta é ser um gênio. Eu me comprometerei aqui (em benefício de meus compatriotas) a tornar claro que é possível fazer um poema épico sem ser um gênio, e mesmo sem ter aprendizado ou muita leitura. Isso deve necessariamente ser de grande utilidade para todos aqueles que confessam que nunca leram e sobre quem o mundo está convencido de que nunca aprendem.]

O capítulo se propõe a examinar as diferentes partes do poema épico: a fábula, os episódios, a moral alegórica, os costumes, as máquinas e as descrições.

Tal como está, esse capítulo contém uma dupla definição de epopeia. É antes de tudo um gênero literário, identificável por uma série de características formais e temáticas que são

\footnotetext{
14 POPE, Alexander. Peri Bathous [1728]. In: The Major Works. Pat Rogers (Ed.). Oxford: OUP, “Oxford World's Classics", 2008, p. 233-234. N. T. O autor do artigo, Dimitri Garncarzyk, apresenta uma versão em francês da citação.
} 
específicas a ele: vamos chamá-la de uma definição genérica de epopeia, detalhada como uma "receita". Mas, como enfatiza a exordia do capítulo, esse gênero em particular ocupa um lugar eminente na ordem da criação literária e, geralmente, entre os empreendimentos humanos: o consenso crítico faz com que seja "a maior obra de que a natureza humana é capaz".

Martin Scriblerus é o duplo satírico do poeta e poeticista Alexander Pope, autor em 1711 do muito sério Essay on Criticism [Ensaio sobre Crítica], no qual poderíamos ler: "Some [critics] dryly plain, without Invention's aid,/ Write dull receipts how poems may be made" [Alguns (críticos) secamente simples, sem a ajuda da Invenção, /Escrevem receitas tediosas sobre como poemas podem ser feitos] ${ }^{15}$.

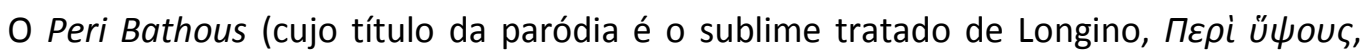
popularizado pela tradução de Boileau no final do século XVII) exemplifica o trabalho dos maus críticos denunciados na poética séria: é uma pseudopoética sem invenção, assim como Scriblerus sugere escrever sem gênio.

Essa passagem de Peri Bathous destaca uma das principais dificuldades da poética na era clássica. Por um lado, como Michel Charles explica,

[...] l'âge rhétorique est par excellence l'âge de l'invention, de la production, dans la mesure où il déculpabilise autant qu'il est possible l'auteur et dédramatise l'écriture, dans la mesure où il va aussi loin qu'il est possible dans l'idée que tout le monde peut pratiquer la littérature. ${ }^{16}$

[(...) a era retórica é por excelência a era da invenção, da produção, na medida em que exonera tanto quanto possível o autor e dramatiza a escrita, na medida em que vai o mais longe possível na ideia de que todos possam praticar literatura.]

Se, de fato, se pode incluir a leitura dos modelos nas receitas, qualquer um pode compor poemas épicos; mas o risco é obviamente distorcer a epopeia na operação. Por outro lado, os poetas clássicos, conscientes desse perigo, exigem do aspirante a poeta uma qualidade individual impensada: o gênio. Essa dupla exigência leva ao paradoxo satirizado por Pope, que, como tradutor de Homero, o poeta heroico, muito provavelmente pensa sinceramente que a epopeia é uma obra poética de grande valor.

A epopeia, no início do século XVIII, é, portanto, objeto de admiração (consenso crítico), do qual surge um desejo (que a poética, ou receita, permitiria satisfazer); mas o entusiasmo deste relato prático (no sentido de que, sem estar satisfeito com a leitura, ele imagina a composição) é temperado por uma intuição: a poética pode produzir epopeias, ou algo mais é necessário ? Se, em suma, a receita de Scriblerus não é suficiente para explicar o que é uma epopeia, como fazê-la?

\footnotetext{
${ }^{16}$ CHARLES, Michel. L'Arbre et la source, op. cit., p. 186.
} 
Será, portanto, uma questão de percorrer um corpus europeu de discursos sobre a epopeia, que, com exceção da do padre Batteux, será obra de poetas épicos como Voltaire, Pope, Danois Ludvig Holberg e o polonês Ignacy Krasicki. Não nos voltaremos à escolha desses autores e sua incorporação a um classicismo internacional, desenvolvido em toda a Europa a partir da recepção do "momento clássico" (Alain Génétiot) do final do século XVII francês, de que já tratamos em outro momento ${ }^{17}$.

Distinguiremos, em um ponto importante, nossa abordagem da de Michel Charles. Lá onde ele fala de "sistema" clássico", nós preferiremos aqui falar de tecnologia clássica. A palavra, emprestada do historiador do romance Nicholas D. Paige ${ }^{18}$, não implica sobredeterminações antropológicas ou sociais, nem a ideia de coerência interna que conota o sistema de palavras; ele enfatiza a dimensão prática e funcional da abordagem clássica. Pope é um bom exemplo: enfatizar os paradoxos teóricos da poética em Peri Bathous não o impede de trabalhar com as ferramentas intelectuais que ele fornece em Essay on criticism ou de compor The Rape of the Lock. Lá onde a ideia de sistema define adeptos e oponentes, a de tecnologia propõe um retrato do poeta ou do crítico em engenharia: a prática da poesia é uma bricolagem entre a herança cultural antiga, a ambição teórica e os desejos contemporâneos. Esses diferentes fatores se combinam, em função das personalidades e dos contextos, para produzir discursos diferentes, sobre quais parece possível propor uma tipologia.

\subsection{Uma ferramenta: Hans Robert Jauss e a tipologia de metodologias genéricas}

Aqui tentaremos responder a uma pergunta aparentemente simples: como definimos, no século XVIII, a epopeia? Como acabamos de salientar, no entanto, a amplitude do cronotopo em consideração (a Europa do século XVIII) proíbe qualquer definição excessivamente unificadora. Se os autores do corpus que montamos compartilham seu uso da tecnologia clássica (que, por outro lado, é rapidamente rejeitada pelos alemães, o que justifica sua ausência em nosso estudo), suas abordagens diferem significativamente. Aqui gostaríamos de dar conta da plasticidade da concepção clássica da poesia épica.

Dividiremos, para isso, as definições do poema épico de nossos autores em três categorias, pelas quais somos gratos a Hans Robert Jauss. Em um artigo intitulado "Littérature médiévale et théorie des genres" [Literatura medieval e teoria dos gêneros] ${ }^{19}$ (que, ao menos,

\footnotetext{
17 Nós nos permitiremos fazer referência a esse assunto em nosso artigo "Comment peut-on être classique ? Les classicismes français et stanislavien entre histoire littéraire et poétique". In : Annales de l'Académie polonaise de sciences - Centre scientifique à Paris, $n^{\circ} 18$, Paris: Académie polonaise des sciences, décembre 2016. Disponível em: http://paris.pan.pl/fr/images/stories/pliki/PDF/Roczniki/R18/Annales\%2018\%20cz-2 105-116.pdf.

18 Ele propõe isso na introdução de seu livro Before Fiction. The Ancient Regime of the Novel. Pittsburgh: UPP, 2011.

19 JAUSS, Hans Robert. Littérature médiévale et théorie des genres. Trad. Éliane Kaufholz. In : Gérard Genette et Tzvetan Todorov (Ed.). Théorie des genres. Paris: Éditions du Seuil, “Points essais", 1996, p. 37-71.
} 
investe tanto na teoria quanto na literatura medieval), esse crítico sugere, sem se aprofundar nela, uma tipologia das maneiras de definir gêneros literários. Essas definições podem ser feitas "de um ponto de vista normativo (ante rem)", "classificador (post rem)" ou "histórico (in re), ou seja, "dans une continuité, où tout ce qui est antérieur s'élargit et se complète par ce qui suit" [em uma continuidade, na qual tudo isso anterior alarga e é completado pelo que se segue] ${ }^{20}$.

O último tipo de definição ganha o apoio de Jauss; ela consiste em não conceder aos gêneros "aucun autre caractère de généralité que celui qui apparaît dans leur manifestation historique" [qualquer outro caráter de generalidade além daquele que aparece em sua manifestação histórica] ${ }^{21}$, ou seja, ao considerar apenas dados empíricos (textos existentes), enquanto os organiza como uma rede intertextual, permite-se que se evite "I'esthétisme de la critique imanente" [o estetismo da crítica imanente] ${ }^{22 ",}$ ou seja, definições com conceitos fechados, encerrados no círculo hermenêutico de uma abordagem puramente monográfica. Ela consiste em considerar como constitutivo do gênero não apenas os pontos comuns, mas também as variações existentes entre as obras que o definem; gênero, em outras palavras, é considerado aqui como uma noção relevante, mas plástica.

Jauss não detalha precisamente as implicações dos outros dois tipos de definições. Parece-lhe claro que as definições ante rem cobrem, grosso modo, a abordagem clássica das categorias genéricas, caracterizada por sua confiança na "universalité normative du canon des genres" [universalidade normativa do cânone dos gêneros] ${ }^{23}$. Consideraremos aqui que uma definição ante rem é baseada em uma série de critérios (de ordem estilística, temática, quantitativa etc.) a priori o que a obra deve satisfazer, no todo ou em grande parte, para justificar seu pertencimento genérico. Essa abordagem parece ser caracterizada por uma forma de realismo genérico (as categorias genéricas existiriam em si mesmas e independentemente de seu conteúdo); mas isso não fornece nenhuma resposta sobre os meios disponíveis para a crítica identificarem esses critérios.

Quanto à definição post rem, ela parece mais vaga do que as duas anteriores. Toda operação crítica não acontece após o fato e todo trabalho sobre os gêneros não é, por definição, classificação? Faz-se necessário provavelmente compreender aqui que os critérios de classificação não preexistem à obra classificada (ante rem), e tampouco são extraídos dela pela análise monográfica e serial do trabalho (in re): a definição post rem limita-se ao registro de uma etiqueta genérica proposta pela recepção da obra. Tal definição é construída pela recepção, sem

\footnotetext{
20 Op. cit., p. 43.

21 Op. cit. p. 42.

22 Op. cit. p. 40

$23 \mathrm{lbid}$.
} 
que haja a ambição de orientá-la e, em suma, constitui uma solução teoricamente falível da abordagem genérica: ela pode ser levada a acolher obras díspares em suas categorias, sem procurar, em particular, refinar a classificação ou alterar os critérios.

A tipologia de Jauss é, certamente, de interesse essencialmente heurístico, e não é certo que os críticos que leremos pratiquem esse ou aquele tipo de definição exatamente no sentido em que Jauss a teria entendido. Ela é, no entanto, particularmente produtiva e fornecerá uma visão geral dos movimentos de crítica épica no século XVIII.

\section{Ante rem: o que a epopeia deve ser}

No século XVIII, apesar do espírito de reforma que parece largamente dominá-lo, permanece na verdade uma reflexão poética amplamente clássica - o que implica que, de fato, nos gêneros literários, ele não partiu nem tão francamente nem tão massivamente quanto pode-se pensar nas definições ante rem. A maneira de praticar essas definições não é necessariamente a mesma que a de Le Bossu ou a de Boileau; mais uma vez, não se trata de assinar um sistema, mas de operar dentro da mesma tecnologia, em que as definições normativas fazem parte das ferramentas padrão. A seu modo, essas definições constituem poderosos instrumentos intelectuais; elas permitem, por exemplo, delinear em poucas palavras o perfil de uma literatura desconhecida, como o padre Pons fez em relação à poesia indiana:

À l'égard de la grande poésie, ou des poèmes de différentes espèces, la nature étant la même partout, les règles sont aussi à peu près les mêmes. L'unité d'action est moins observée dans leurs Pouzânam et autres poèmes, qu'elle ne n'est en particulier dans Homère et Virgile. J'ai pourtant vu quelques poèmes, et entre autres le $d^{\prime}$ Harmapouranam, où l'on garde plus scrupuleusement l'unité d'action. ${ }^{24}$

[Em relação à grande poesia, ou poemas de espécies diferentes, a natureza sendo a mesma em todos os lugares, as regras também são aproximadamente as mesmas. A unidade de ação é menos observada em seus Pouzânam e outros poemas, do que em Homero e Virgílio. No entanto, tenho visto alguns poemas, e outros, de Harmapouranam, nos quais se mantém escrupulosamente a unidade da ação.]

Para o comparatista de hoje, a aplicação do critério neo-aristotélico de unidade de ação à poesia indiana pode parecer incongruente; mas para o curioso leitor do século XVIII, este parágrafo fornece informações preciosas: uma categorização genérica ("grande poesia", portanto mais ou menos épica), um critério ("unidade de ação"), uma referência canônica ("Homero e Virgílio"). A comparação é justificada por uma fundação nessa espécie de regras

\footnotetext{
${ }^{24}$ Lettre du père Pons, missionnaire de la Compagnie de Jésus, au p. Du Halde de la même Compagnie. À Careical, sur la côte de Tanjaour, aux Indes orientales, ce 23 novembre 1740. In : Lettres édifiantes et curieuses, écrites des Missions étrangères par quelques missionnaires de la Compagnie de Jésus. Paris: p. G. Le Mercier, t. XXVI, 1743, p. 227-228.
} 
(com algumas variações: "aproximadamente a mesma") que, se hoje soam como etnocêntricas, garantiram no século XVIII a igual dignidade crítica de literatura recém-descoberta.

Examinaremos aqui dois discursos constitutivos da abordagem ante rem, datados do século XVIII: Alexander Pope, que, em Essay on criticism, descreve a manifestação na história das regras fundadas na natureza; e Charles Batteux, tradutor de Aristóteles, que propõe uma breve epistemologia da obra do crítico.

\subsection{Pope: a fábula do jovem Virgílio}

Em Essay on criticism de 1711, Pope justifica, de maneira séria e particularmente abstrata, o tipo de poética normativa da qual o Peri Bathous é a sátira, na forma do que pode ser chamado de fábula do jovem Virgílio ${ }^{25}$. Como o título do poema indica, o objetivo não é fornecer as regras da arte, mas as do discurso sobre a arte, e não devemos esperar uma definição muito precisa do que épico é concretamente; a obra, no entanto, deixa muito claro o que uma epopeia deve ser.

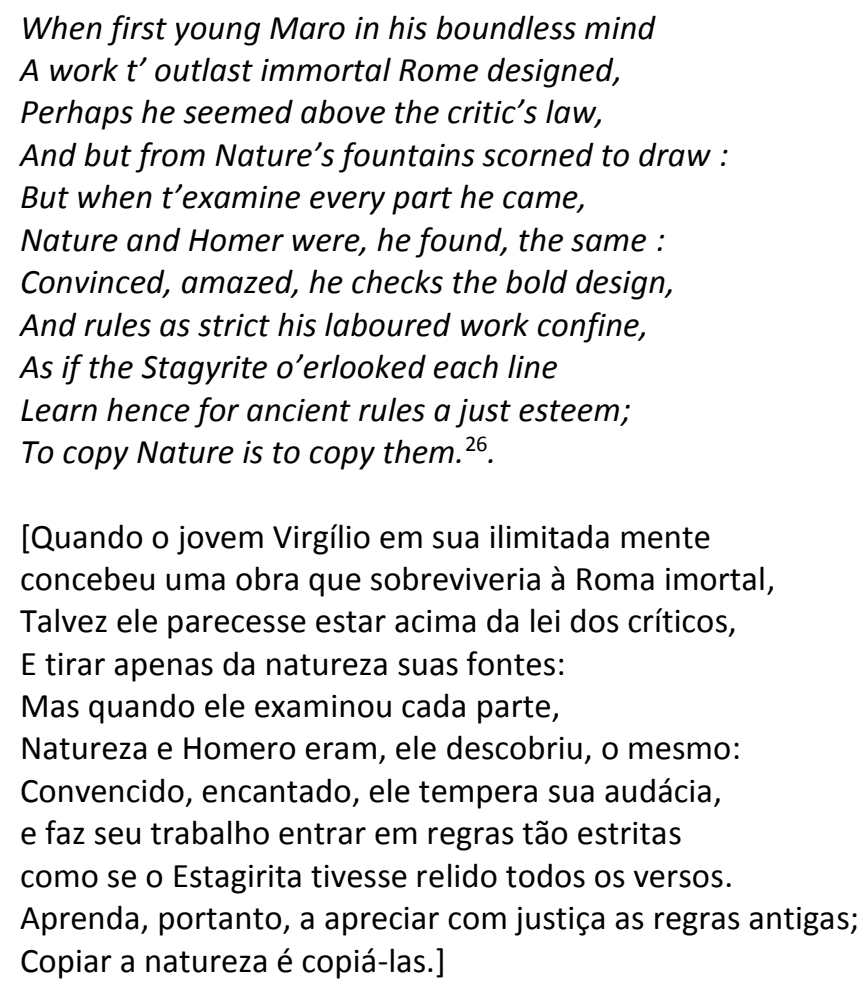

Os vs. 130 a 138 contêm o conto (narração da carreira de Virgílio); os vs. 139-140 a lição (no imperativo), que convida os poetas à imitação dos antigos, sendo estes últimos exemplos da

\footnotetext{
${ }^{25}$ A ideia de ser ler essa passagem como "Pope's fable of a young Virgil" é proposta em : NISBET, Hugh B. ; RAWSON, Claude (Ed.). The Cambridge History of Literary Criticism, t. IV, "Editors' preface", p. xvi.

${ }^{26}$ POPE, Alexander. An Essay on Criticism. In: in The Major Works, op. cit., p. 22. N. T. O autor do artigo apresentou uma versão, em francês, do poema citado.
} 
prática poética contemporânea ("hence"), porque agiam de acordo com a natureza; a repetição de "copy" sublinha essa transitividade. A ideia é clássica, típica do Partido dos Anciãos, e mostra pouca originalidade.

A contribuição de Pope está mais na história. As duas primeiras linhas enfatizam a grandeza de Virgílio, enquanto enfatizam que ainda está por vir: Virgílio ainda é jovem e, portanto, ainda não alcançou a previsão oximorônica (sobrevivendo à Cidade imortal). Essa glória futura se deve à liberdade infinita ("boundless") de Virgílio, que o livraria das regras pelas quais o crítico ("the critic"), caráter abstrato (por enquanto), é o depositário? A natureza está sempre disponível: portanto, não há necessidade de se preocupar com a mediação do metadiscurso. Esse design arrojado é moderado apenas pela lecture [leitura] de Homero; leitura analítica, em que o poeta latino divide o poema em partes ("every part"). A leitura de Homero tem um duplo efeito sobre ele. O maravilhamento ("amazed") é o efeito normal da epopeia (porque "l'épopée fait naître l'admiration"27 [a epopeia gera admiração]); aqui a convicção ("convinced") a precede: a emoção é antes de tudo intelectual (e o maravilhamento que se segue é provavelmente tanto um "eurêka !" poético quanto um sentimento estético). A grandeza de Virgílio o tornou capaz de acessar a Natureza: foi por isso que ele percebeu que Homero não é um prisma essencial entre a natureza e a posteridade, mas uma manifestação da própria Natureza (aquele que, não tendo predecessor, teve que tirar "das próprias fontes da natureza"). Portanto, não há mais conflito entre o gênio de Virgílio e as leis críticas, que são incorporados no final do conto em Aristóteles ("o Estagirita"). Este último, tendo derivado as regras da primeira poética da leitura de Homero, também operava de acordo com a natureza.

Em resumo, natureza é o termo comum de todos esses autores: Aristóteles e Virgílio poderiam ter trabalhado com a natureza, mas o trabalho fundador de Homero os salvou desse problema. A garantia deste modelo é a secundariedade do teórico: a imitação de Homero é suficiente para Virgílio, e Aristóteles, mais que uma referência, é uma garantia de que o texto o mostra olhando majestosamente por cima do ombro ("esquecido") por Virgílio. As gerações seguintes podem assim dispensar a teoria e considerar a Eneida como um comentário de Homero: "Still with itself compared, his text peruse;/And let you comment be the Mantuan Muse. ${ }^{28}$ [Ainda comparando-o com ele mesmo, compile seu texto; e deixe seu comentário ser a Musa do Mantuano].

\footnotetext{
${ }^{27}$ BATTEUX, Charles. Cours de Belles-lettres, ou principes de la littérature. Nouvelle édition. Paris : Desaint et Saillant, 1753 , t. II, p. 11.

28 POPE, Alexander. An Essay on Criticism. In: The Major Works, op. cit., p. 22.N. T. O autor do artigo apresenta uma versão em francês do trecho citado.
} 
Em resumo, a fábula de Virgílio apenas ilustra o início de um processo que é a manifestação do eterno na história e que não tem motivo para deixar de funcionar. $O$ golpe de gênio aqui é abster-se de qualquer anotação sobre o que é concretamente uma epopeia conforme essas regras da natureza e, ao mesmo tempo, evitar qualquer risco de receita; a leitura de textos é a única perspectiva admissível, e o local, se não uma revelação, é, pelo menos, uma compreensão inacessível por outros meios. O conhecimento da epopeia é, nesse sentido, um conhecimento prático.

\subsection{Batteux: o trabalho de Aristóteles}

Se alguém não quer ficar satisfeito com uma nova leitura de Homero e se deseja tirar proveito do trabalho de Aristóteles, deve justificar a abordagem poética. Como Aristóteles obteve acesso a essas regras a priori?

$\mathrm{Na}$ introdução aos Quatro Poetas, o Padre Batteux descreve como o processo aristotélico funciona. Trata-se de justificá-lo contra ataques, como os dos "Modernes de la Querelle" [Modernos da Querela entre Antigos e Modernos], que contestariam o valor do próprio corpus que racionaliza a teoria, invalidando assim o valor de um discurso com base em sua análise.

Lorsque Aristote entreprit d'écrire une poétique, toutes les idées relatives à la poésie étaient préparées : il y avait des modèles dans tous les genres, en très grand nombre, exécutés par les plus grands maîtres. [...] Dans une si grande multitude d'ouvrages, on pouvait trouver toutes les variétés et toutes les beautés possibles du genre. On dira qu'on y trouvait encore plus les défauts. Cela pouvait être. Mais, quand il est question de former un art, c'est-à-dire, d'indiquer à des artistes ce qu'ils doivent faire ou éviter pour avoir du succès, les défauts observés servent autant que les beautés. Ils servent plus, parce qu'ils font sortir plus fortement la règle. La poésie était donc assez avancée du temps d'Aristote, pour qu'il fût en état d'en poser les vrais principes, et d'en développer les détails. ${ }^{29}$

[Quando Aristóteles se comprometeu a escrever uma poética, todas as ideias relacionadas à poesia estavam preparadas: havia modelos em todos os gêneros, em muito grandes números, executado pelos maiores mestres. [...] Dentro dessa multiplicidade de obras, é possível encontrar todas as variedades e todas as belezas possíveis do gênero. Podemos, contudo, dizer que parece que havia ainda mais falhas nele. Poderia ser. Mas, quando se trata de formar uma arte, ou seja, dizer aos artistas o que eles devem fazer ou evitar para ter sucesso, os defeitos observados servem tanto quanto as belezas. Eles servem mais, porque divulgam a regra com mais força. A poesia estava, portanto, suficientemente avançada no tempo de Aristóteles, para que ele estivesse em posição de estabelecer seus verdadeiros princípios e desenvolver seus detalhes.]

O primeiro ponto levantado pelo padre Batteux é a justificativa do corpus. A poética, nesse sentido, é uma abordagem da organização de textos do passado, da qual Batteux elogia

\footnotetext{
${ }^{29}$ BATTEAUX, Charles. Les Quatre Poëtiques. Paris : Saillant ; Nyon : Desaint, “Avant-propos”, 1771, t. I, p. 2-3.
} 
os próprios defeitos, dando às imperfeições das obras um maior valor heurístico do que suas qualidades. A crítica que se segue ao agrupamento do corpus não é, portanto, uma apologética, se ela lê os textos para identificar os "defeitos" e as belezas; é a etapa preliminar na produção de padrões que deve "formar uma arte". A retrospecção, portanto, anuncia a prospecção do campo de possibilidades, que assume a forma de instruções que antecedem os novos textos poéticos e os orientam de acordo com o gosto do público (a relevância da regra advinda do "sucesso" que ela garante).

Modelos e contra modelos são, portanto, usados para ilustrar "regras"; a questão remanescente é como os defeitos aparecem, se aparecerem nos textos das testemunhas que servem para formar o padrão. Duas respostas diferentes podem ser dadas a essa pergunta.

O primeiro é histórico. Batteux justifica Aristóteles em um contexto em que o abundante florescimento da literatura grega antiga já constituía um reservatório de "ideias relacionadas à poesia", uma espécie de pré-consciência teórica coletiva que Aristóteles explicaria essencialmente. $\mathrm{O}$ corpus era grande o suficiente para permitir comparações de padrões e desvios; sem mencionar que os testemunhos antigos dos "sucessos" dos autores tornam possível identificar quem eram "os maiores mestres" da época e os opõem aos autores medíocres.

Uma segunda resposta seria que os critérios de gosto são encontrados na própria natureza e são as intuições do tipo platônico que procedem dos julgamentos fundadores de Aristóteles. A imitação da natureza é, para Batteux, o "mesmo princípio" que funda todas as artes, mas também forma o gosto e o julgamento que permitem, intuitivamente e depois racionalmente, para apreciá-los. A rejeição do relativismo, portanto, serve, em uma síntese paradoxal, para justificar a autoridade do texto antigo.

Este simples parágrafo do Padre Batteux é indicativo da grande tensão que atravessou o empreendimento teórico no século XVIII. Em perspectiva, visa regular a produção contemporânea e alinhá-la ao gosto do público; mas, ao mesmo tempo, prossegue aplicando princípios racionais, cuja existência atemporal deve ser assumida para que eles preexistam os textos que permitem julgar. Adota uma postura moderna: o gosto do dia é o mais racional que apareceu na história da humanidade. Ao mesmo tempo, o padre Batteux continua sendo um "professor de antiguidades", impulsionado pelo amor aos textos: a poética pode, portanto, ser apenas retrospectiva, ou seja, indutiva (e não silogística). O problema que ela encontra aqui é que, se os textos que ela está estudando contêm falhas, eles não são suficientes para uma padronização. Ao resistir às desculpas sistemáticas dos antigos praticados, por exemplo, por Anne Dacier (de cujos entusiasmos ele também zomba), o padre Batteux herda os problemas dos modernos tanto quanto os dos antigos. 


\section{In re: tudo o que a epopeia pode ser}

As definições associam novamente a preocupação monográfica à abordagem serial: o trabalho redefine o gênero, concebido como uma categoria plástica, mas não é sui generis, o que equivaleria a negar a relevância da noção de gênero (ela é a esse tipo de conclusão radical que Croce chega), enquanto Jauss sustenta que o gênero participa tanto da composição quanto da recepção da obra. Esta é sem dúvida a definição mais dinâmica de gêneros literários na tipologia de Jauss, e também a que oferece mais espaço para a transformação de cânones e, portanto, talvez a mais perigosa para a tecnologia clássica.

O poder desse tipo de definição foi particularmente apreciado por um dos primeiros filólogos medievais do século XVIII, Étienne Barbazan (1696-1770). Para legitimar a epopeia medieval, ele propõe refazer a definição de gênero fora da estrutura aristotélica (mas ainda observando um critério clássico, a extensão):

Nos anciens poètes français ne se bornaient point à un seul genre de poème; ils en composaient de différentes espèces. II nous reste encore des poèmes de leur façon, auxquels nous pouvons donner le nom d'épiques, quoiqu'ils ne soient point faits selon les règles prescrites par Aristote, qui paraissent leur avoir été inconnues. Tels sont le poème de la vie d'Alexandre, composé par Lambert li Cors, et par Alexandre de Paris ; celui de la vie du Connétable Duguesclin, fait par Cuvelier; et celui de la conquête de Jerusalem, dont Renax est Auteur. Chacun de ces poèmes contient environ dix-huit à vingt mille vers. ${ }^{30}$

[Nossos antigos poetas franceses não se limitavam a um único tipo de poema; eles são compostos de espécies diferentes. Ainda temos poemas à sua maneira, aos quais podemos dar o nome de épicos, embora não sejam feitos de acordo com as regras prescritas por Aristóteles, que lhes parecem desconhecidas. Estes são os poemas da vida de Alexandre, compostos por Lambert li Cors e por Alexandre de Paris; a da vida do Connétable Duguesclin, feita por Cuvelier; e o da conquista de Jerusalém, da qual Renax é o autor. Cada um desses poemas contém cerca de dezoito a vinte mil versos.]

A necessidade de reformar a categoria épica aparece pela primeira vez no que diz respeito à diversidade genérica da poesia medieval; o apego dos vários poemas (que hoje se enquadram nas categorias de canção de gesta ou romance antigo) à categoria de receitas épicas de uma dupla preocupação de legitimar um novo corpus para o público e à economia de categorias em relação à crítica: em qual vemos a dimensão serial da abordagem. Quanto à sua dimensão monográfica, estão indicadas algumas páginas abaixo:

[...] quoique les Auteurs ne paraissent point s'être formés sur les beaux modèles de l'antiquité, on retrouve néanmoins dans quelques-uns de leurs ouvrages, des traces

\footnotetext{
${ }^{30}$ BARBAZAN, Étienne. Fabliaux et contes des poetes françois des XIII, xIV et xVes Siécles, Tirés des meilleurs Auteurs.
} Paris : Vincent, 1761, “Préface", p. xiii-xiv. 
des Anciens; et dans ce dont ils ne sont redevables qu'à leur propre fond, il y a des traits qui feraient honneur à notre siècle. ${ }^{31}$

[(...) embora os Autores não pareçam ter sido formados nos bons modelos da antiguidade, encontramos, ao menos em algumas de suas obras, traços dos Antigos; e nisso eles são devedores apenas de seus próprios méritos, existem ali características que honrariam nosso século.]

Se a comparação com os Antigos é legitimadora, é apenas um apêndice do surgimento de um critério monográfico ("seu próprio histórico"), que convida a uma leitura em que o prazer da novidade tem precedência sobre o reconhecimento.

Vamos nos concentrar aqui no exame de duas metodologias in re: a primeira é a implementada por Voltaire no Essai sur la poésie épique [Ensaio sobre a poesia épica], que constitui um exemplo perfeito dessa abordagem; a segunda diz respeito à maneira como o poeta dinamarquês Ludvig Holberg (1684-1754), autor de uma epopeia cômica, considera que seu trabalho faz parte do corpus épico do século XVIII.

\subsection{Voltaire: da definição histórica ao auto pedido de desculpas}

A estrutura do Essai sur la poésie épique [Ensaio sobre a poesia épica] (primeira versão em inglês: 1728, versão autorizada em francês: 1732) de Voltaire é reveladora do processo: um primeiro capítulo, "Des différents goûts des peuples" [Os diferentes gostos dos povos], é dedicado ao gênero épico em geral (e em particular para limitar os critérios a priori), quando os seguintes são dedicados a uma longa série de poetas épicos (Homero, Virgílio, Lucano, Trissino, Camões, Tasso, Don Alonzo de Ercilla e Milton). A partir de uma definição mínima do gênero, cada autor é, portanto, objeto de uma monografia, inserida em uma série que redefine a gênero em cada nova etapa (e é claro que não é exaustivo). Vamos nos concentrar particularmente aqui na metodologia desenvolvida no primeiro capítulo, que começa com um ataque às definições normativas do classicismo.

La plupart [des commentateurs] ont discouru avec pesanteur de ce qu'il fallait sentir avec transport; et quand même leurs règles seraient justes, combien peu seraientelles utiles! Homère, Virgile, le Tasse, Milton, n'ont guère obéi à d'autres leçons qu'à celles de leur génie. Tant de prétendues règles, tant de liens, ne serviraient qu'à embarrasser les grands hommes dans leur marche, et seraient d'un faible secours à ceux à qui le talent manque. II faut courir dans la carrière, et non pas s'y traîner avec des béquilles. Presque tous les critiques ont cherché dans Homère des règles qui n’y sont assurément point. ${ }^{32}$

[A maioria (dos comentaristas) falou com gravidade sobre o que se deveria sentir com a transposição; e mesmo que suas regras fossem justas, quão poucas seriam úteis! Homero, Virgílio, Tasso, Milton dificilmente obedeceriam a outras lições além

\footnotetext{
31 Op. cit., p. xxvii-xxviii

32 VOLTAIRE. Essai sur la poésie épique. In: The Complete Works of Voltaire. Oxford: Voltaire Foundation, t. 3B, p. 398.
} 
das de seu gênio. Tantas regras, tantos elos, só serviriam para embaraçar os grandes homens em sua marcha e seriam de pouca ajuda para os que não têm talento. Deverse-ia correr pelas pedreiras, não se arrastar de muletas. Quase todos os críticos procuraram regras em Homero que certamente não estão lá.]

A crítica, em suma, é uma racionalização que disseca o corpus antigo. Em modelo que parte da forma para o sentido, Voltaire substitui o do impulso individual do gênio e, ao fazê-lo, mina a relação descomplexada da era retórica com a composição, distinguindo entre "grandes homens" e "aqueles a quem Ihes falta o talento".

Se alguns indivíduos valem (poeticamente) mais que outros, sua individualidade é, no entanto, composta. Ela comporta uma parte de eleição (talento ou gênio individual), mas também depende de fatores contextuais: o poeta é tributário dos costumes de seu país, do conhecimento de seu tempo, das restrições de sua língua. O poema épico deriva, portanto, tanto da inspiração individual quanto das determinações socio-históricas. A abordagem comparatista, desse ponto de vista, tem o desafio de não testar a universalidade das regras, mas, ao contrário, tornar aparente a variedade das obras:

Si un de ceux qu'on nomme savants, et qui se croient tels, venait vous dire : " Le poème épique est une longue fable inventée pour enseigner une vérité morale, et dans laquelle un héros achève quelque grande action, avec le secours des dieux, dans l'espace d'une année" ; il faudrait lui répondre : Votre définition est très fausse, car, sans examiner si l'lliade d'Homère est d'accord avec votre règle, les Anglais ont un poème épique dont le héros, loin de venir à bout d'une grande entreprise par le secours céleste, en une année, est trompé par le diable et par sa femme en un jour, et est chassé du paradis terrestre pour avoir désobéi à Dieu. Ce poème cependant est mis par les Anglais au niveau de l'lliade, et beaucoup de personnes le préfèrent à Homère avec quelque apparence de raison. ${ }^{33}$

[Se um daqueles chamados eruditos, e que se acreditam assim, vierem lhe dizer: "O poema épico é uma longa fábula inventada para ensinar uma verdade moral, e na qual um herói realiza uma grande ação, com a ajuda dos deuses, no espaço de um ano"; você teria que responder: sua definição é muito falsa, porque, sem examinar se a llíada de Homero concorda com sua regra, os ingleses têm um poema épico cujo herói, longe de superar um grande empreendimento pela ajuda celestial, em um ano, é enganado pelo diabo e por sua esposa em um dia, e é expulso do paraíso terrestre por ter desobedecido a Deus. Esse poema, no entanto, é trazido pelos ingleses ao nível da llíada, e muitas pessoas o preferem a Homero com alguma aparência de razão.]

Antes da genialidade individual de Milton, foi a aprovação geral do público inglês que deu à Paradise Lost a legitimidade necessária para impor uma redefinição do gênero. Toda a teoria clássica é confrontada com o problema da genialidade, como vimos na introdução; mas Boileau, Pope e os defensores da poética normativa são capazes de fornecer definições de gênio compatíveis com a ideia de norma. A verdadeira originalidade de Voltaire como comparatista é dar ao contexto do autor maior legitimidade do que à genialidade do indivíduo e à abstração de

33 Op. cit., p. 398-399. 
normas. Essa importância do fator histórico na poética é herdada dos argumentos dos apologistas de Homero durante a discussão. Se Anne Dacier, por exemplo, aderiu a um conceito ante rem do poema épico (seguindo de perto as teorias de Le Bossu), sua abstração não lhe permitiu atenuar o que Larry Norman chama de "o choque do antigo": a contextualização assim, tomou um lugar crescente e limitou cada vez mais o lugar do discurso teórico abstrato.

Voltaire leva esse movimento de valorização do contexto a ponto de defender um nominalismo genérico: categorias genéricas são rótulos que condicionam um certo tipo de recepção antecipada que um certo tipo de conteúdo:

Le poème épique, regardé en lui-même, est donc un récit en vers d'aventures héroïques. Que l'action soit simple ou complexe; qu'elle s'achève dans un mois ou dans une année, ou qu'elle dure plus longtemps; que la scène soit fixée dans un seul endroit, comme dans l'lliade; que le héros voyage de mers en mers, comme dans l'Odyssée; qu'il soit heureux ou infortuné, furieux comme Achille, ou pieux comme Énée; qu'il y ait un principal personnage ou plusieurs; que l'action se passe sur la terre ou sur la mer ; sur le rivage d'Afrique, comme dans la Lusiada ; dans l'Amérique, comme dans l'Araucana; dans le ciel, dans l'enfer, hors des limites de notre monde, comme dans le Paradis de Milton; il n'importe : le poème sera toujours un poème épique, un poème héroïque, à moins qu'on ne lui trouve un nouveau titre proportionné à son mérite. Si vous vous faites scrupule, disait le célèbre M. Addison, de donner le titre de poème épique au Paradis perdu de Milton, appelez-le, si vous voulez, un poème divin, donnez-lui tel nom qu'il vous plaira, pourvu que vous confessiez que c'est un ouvrage aussi admirable en son genre que l'lliade.

Ne disputons jamais sur les noms. Irai-je refuser le nom de comédies aux pièces de M. Congrève ou à celles de Calderon, parce qu'elles ne sont pas dans nos mœurs ? ${ }^{34}$

[O poema épico, visto por si só, é, portanto, uma história em verso de aventuras heroicas. Se a ação é simples ou complexa; se termina em um mês ou um ano ou dura mais; que a cena seja fixada em um só lugar, como na llíada; que o herói viaje de mar a mar, como na Odisseia; que ele seja feliz ou infeliz, furioso como Aquiles ou piedoso como Enéias; se existe um personagem principal ou mais; se a ação ocorre em terra ou no mar; na costa da África, como em Os Lusíadas; na América, como em Araucana; no céu, no inferno, além dos limites do nosso mundo, como no Paraíso de Milton; não importa: o poema sempre será um poema épico, um poema heroico, a menos que encontremos um novo título proporcional ao seu mérito. Se você está com escrúpulos, disse o famoso Sr. Addison, para dar o título de poema épico ao Paraíso Perdido de Milton, chame-o, se quiser, de um poema divino, dê o nome que quiser, desde que você confesse que é uma obra tão admirável em seu gênero quanto a llíada.

Nunca discutamos sobre nomes. Devo recusar o nome das comédias das peças do Sr. Congrève ou do Calderon, porque não estão em nossos costumes?]

O aumento do corpus (isto é, a extensão do termo poema épico) tem como corolário o enfraquecimento de sua intenção (o número e o grau de precisão de seus critérios). Isso tem a vantagem significativa de evitar o tipo de contorção interpretativa para a qual os proponentes da doutrina normativa são empurrados.

34 Op. cit., p. 401-402. 
Voltaire, no entanto, é sensível ao perigo apresentado por sua abordagem: ele corta, no espaço e no tempo, subconjuntos humanos que, portanto, correm um risco de essencialização à qual ele é filosoficamente contrário (esse tipo de risco não existe no sistema anterior, que considera que as regras são fundamentadas na natureza). Portanto, é apropriado substituir as definições normativas insatisfatórias por uma nova definição, baseada na natureza humana: o objetivo da pergunta e a dificuldade é saber o que as nações educadas têm em comum e em que elas se diferem. Voltaire propõe, assim, um certo número de características da epopeia, e encontra nessa ocasião o registro deôntico da poética normativa:

Un poème épique doit partout être fondé sur le jugement, et embelli par l'imagination: ce qui appartient au bon sens appartient également à toutes les nations du monde. Toutes vous diront qu'une action une et simple, qui se développe aisément et par degrés, et qui ne coûte point une attention fatigante, leur plaira davantage qu'un amas confus d'aventures monstrueuses. On souhaite généralement que cette unité si sage soit ornée d'une variété d'épisodes qui soient comme les membres d'un corps robuste et proportionné. Plus l'action sera grande, plus elle plaira à tous les hommes, dont la faiblesse est d'être séduits par tout ce qui est au delà de la vie commune. II faudra surtout que cette action soit intéressante, car tous les cœurs veulent être remués; et un poème parfait d'ailleurs, s'il ne touchait point, serait insipide en tout temps et en tout pays. Elle doit être entière, parce qu'il n'y a point d'homme qui puisse être satisfait s'il ne reçoit qu'une partie du tout qu'il s'est promis d'avoir. ${ }^{35}$

[Um poema épico deve, sobretudo, ser fundado no julgamento e embelezado pela imaginação: o que pertence ao senso comum também pertence a todas as nações do mundo. Tudo dirá que uma ação única e simples, que se desenvolve facilmente e gradualmente, e que não custa uma atenção cansativa, agradará mais do que um monte confuso de aventuras monstruosas. Existe um desejo geral de que esta unidade sábia seja adornada com uma variedade de episódios que sejam como membros de um corpo robusto e proporcional. Quanto maior a ação, mais ela agradará todos os homens, cuja fraqueza será seduzida por tudo o que está além da vida comum. Acima de tudo, essa ação terá que ser interessante, porque todos os corações querem ser movidos; além disso, um poema perfeito, se não tocasse, seria insípido em todos os momentos e em todos os países. Ela deve ser inteira, porque não há homem que possa ficar satisfeito se receber apenas uma parte do todo que se prometeu que teria.]

Racionalidade, ornamentos ficcionais, unidade de ação, episódios, nobreza, vicissitudes, desfecho: Voltaire recupera, a todo custo, os critérios mais clássicos, embora formulados da maneira mais filosófica e geral possível, para escapar do tecnicismo dos termos da poética aristotélico-horaciana dos clássicos, que testemunham uma ancoragem contextual específica:

Telles sont à peu près les principales règles que la nature dicte à toutes les nations qui cultivent les lettres; mais la machine du merveilleux, l'intervention d'un pouvoir céleste, la nature des épisodes, tout ce qui dépend de la tyrannie de la coutume, et de cet instinct qu'on nomme goût, voilà sur quoi il y a mille opinions, et point de règles générales. ${ }^{36}$

\footnotetext{
35 Op. cit., p. 402-403.
}

36 Op. cit., p. 403. 
[Essas são apenas as principais regras que a natureza dita para todas as nações que cultivam letras; mas a máquina do maravilhoso, a intervenção de um poder celeste, a natureza dos episódios, tudo isso depende da tirania do costume, e desse instinto que chamamos de gosto, é isso que existem milhares de opiniões, e sem regras gerais.]

Voltaire, portanto, propõe uma definição mínima capaz de acomodar todas as características contingentes das obras: é forte o suficiente para resistir à extrema disparidade de documentos empíricos, mas flexível o suficiente para integrar essa disparidade em seus próprios critérios. Voltaire, nisso, oferece uma definição in re, e seus critérios, que são amplamente herdados da poética normativa, não alteram o desejo de plasticidade teórica que ele expressa.

Se essa plasticidade é a principal vantagem da definição teórica de Voltaire, ela também é responsável pelo principal fator de prazer na leitura de epopeias: certamente, o comparatismo permite identificar critérios suficientemente gerais para serem universais, mas é no espetáculo da variedade de obras e das sociedades humanas que reside sua verdadeira vantagem.

II n'y a point de monuments en Italie qui méritent plus l'attention d'un voyageur que la Jérusalem du Tasse. Milton fait autant d'honneur à l'Angleterre que le grand Newton. Camoëns est en Portugal ce que Milton est en Angleterre. Ce serait sans doute un grand plaisir, et même un grand avantage pour un homme qui pense, d'examiner tous ces poèmes épiques de différente nature, nés en des siècles et dans des pays éloignés les uns des autres. II me semble qu'il y a une satisfaction noble à regarder les portraits vivants de ces illustres personnages grecs, romains, italiens, anglais, tous habillés, si je l'ose dire, à la manière de leur pays. ${ }^{37}$

[Não há monumentos na Itália que mereçam a atenção de um viajante mais do que a Jerusalém de Tasso. Milton faz tanta honra à Inglaterra quanto o grande Newton. Camões é em Portugal o que Milton é na Inglaterra. Sem dúvida, seria um grande prazer, e até uma grande vantagem para um homem que pensa, examinar todos esses poemas épicos de natureza diferente, nascidos em séculos e em países distantes um do outro. Parece-me que há uma nobre satisfação em olhar para os retratos vivos desses ilustres personagens gregos, romanos, italianos e ingleses, todos vestidos, se me atrever a dizer, no estilo de seu país.]

A epopeia, do gênero universal que domina o edifício abstrato da hierarquia dos gêneros na poética normativa, torna-se aqui a expressão privilegiada do gênio singular dos povos.

Essa valorização do contingente tem também uma função apologética. Se cada poema é único e, além disso, "il est honteux pour nous [Français], à la vérité, que les étrangers se vantent d'avoir des poèmes épiques, et que nous, qui avons réussi en tant de genres, nous soyons forcés d'avouer, sur ce point, notre stérilité et notre faiblesse" 38 [é vergonhoso para nós (franceses), na verdade, que os estrangeiros se vangloriem de ter poemas épicos e que nós, que conseguimos

\footnotetext{
37 Op. cit., p. 409-410.

38 Op. cit., p. 492-493.
} 
tantos gêneros, sejamos obrigados a admitir, neste ponto, nossa esterilidade e nossa fraqueza], o poema que registrará a França após a série de poemas analisados no ensaio merecerá a curiosidade comparativa do público universal e a gratidão particular do público francês. O padre Batteux, considerando que Voltaire, ao propor uma definição desse tipo, propõe redefinir o gênero em função de seu poema, em vez de se curvar a padrões dos quais ele não é mestre, o acusa de falta de sinceridade:

\begin{abstract}
Que ne mettait-il de bonne grâce en titre Apologie de ma Henriade. Il a fait ce poème avant de savoir les règles, et ensuite il veut faire des règles sur son Poème, et pour cela renverser toutes les idées communes, par un paralogisme farci d'une érudition étincelante, jetée rapidement pour en dérober le faux. ${ }^{39}$

[Por que ele não colocou graciosamente no título Apologia à minha Henriade. Ele fez esse poema antes de conhecer as regras e, em seguida, deseja criar regras sobre seu poema, e, com isso, isso anular todas as ideias comuns, por um paralogismo recheado de uma erudição cintilante, jogada rapidamente para encobrir o falso.]
\end{abstract}

\title{
3.2 Holberg: no trabalho individual
}

A definição in re, histórica, segundo Jauss, é uma definição que confere à contingência um lugar amplo. Em contraste com as definições ante rem que constroem um objeto ideal do qual textos singulares devem se aproximar, ele se adapta às obras e, ao fazê-lo, legitima a individualidade poética. As reflexões de Ludvig Holberg sobre seu poema heroico Peder Paars (uma Eneida em um copo de água, que conta uma navegação incrível no Kattegat) ilustram essa nova atenção dada ao particular.

$\mathrm{Na}$ primeira de suas cartas autobiográficas a um homem ilustre (Epistula ad virum perillustrem), Holberg observa em 1728:

Complexus sum non ita pridem quartet libris historiam Petri Paarsii, satyra poematis in eos dirigitur, qvi opera sunt in nihilo scribendo, quique famæ and adsignare conantur, quæ in silencio ac obscurecendo Repositor esse maxime debent; vereor, ne tela, quæ in alios torsi, em mim eodem jure retorqueantur $[\ldots]^{40}$.

[Dividi a história de Peder Paars em quatro livros, não faz muito tempo; essa sátira do poema é dirigida contra aqueles que cuidam de escrever sobre nada e que querem prometer à glória coisas que absolutamente devem se limitar ao silêncio e à obscuridade. Temo que as características que direcionei para os outros sejam corretamente referidas para mim (...).]

\footnotetext{
${ }^{39}$ BATTEAUX, Charles. Parallèle de la Henriade et du Lutrin. Paris, s. n., 1748, p. 61.

40 HOLBERG, Ludvig. Ludovici Holbergii ad virum perillustrem *** epistola [Første levnedsbrev, 1728]. As obras integrais de Ludvig Holberg (tanto latinas como dinamarquesas) foram objeto de uma edição crítica muito completa que pode ser encontrada online no seguinte endereço: holbergsskrifter.dk._N.T. Quanto ao trecho citado, o autor do artigo apresentou uma versão em francês, a partir da qual fizemos a versão em português.
} 
A coincidência da data com a publicação do Peri Bathous deve ser realmente vista apenas como coincidência. A mesma carta contém o relato da estadia de Holberg em Londres e Oxford em 1706-1708, na qual a literatura ocupa muito pouco lugar. De qualquer forma, esta breve passagem (tomada no exórdio da carta) resume o projeto de Peder Paars com uma crítica aos grandes mestres que lembram as do inglês Pope. Eles se esforçam para preencher um formulário; é nesse sentido que eles "estão ocupados escrevendo sobre nada [operosi sunt in nihilo scribendo]", e o tipo de "glória [fama]" que eles esperam é obviamente proporcional ao tamanho do gênero em que eles estão tentando operar.

A descida da forma, no sentido, é criticada aqui em termos que lembram Voltaire (o pequeno mestre se inclina sob o peso do grande gênero) e Pope (a operosi sugere trabalhos trabalhosos e mecânicos): a empresa está, em todo caso, condenada à obscuridade. Se Pope, também conhecido por Scriblerus, executou a reductio ad absurdum dos tratados poéticos, Holberg parece considerar Peder Paars como a reductio ad absurdum dos poemas produzidos no modelo mecanicista de Scriblerus.

Em uma carta autobiográfica amplamente posterior, Holberg também comenta a tradução de sua obra para o alemão ${ }^{41}$ :

Jeg kan her ikke forbigå, at melde noget om den tyske oversættelse af Peder Paars. At samme Oversættelse stikker ikke saa meget i øjnene, som den Danske Original, er ingen Under, thi deslige Skrifter tabe all deres dyd udi fremmed klædning. Det vilde gå ligeså til med den engelske Hudibras og andre skrifter af samme natur, hvilke derudover ikke blive oversatte. Jeg laster ikke oversætterens arbejde. Jeg er ej heller beqvem nok til at dømme om det tyske sprog. Jeg vil kun alleene sige, at deslige komiske Poemata ingen anseelse have uden i hjemgjorde klæder, hvorudover jeg stedse haver rådet fra dette skrifts oversættelse. ${ }^{42}$

[Não posso deixar de fazer alguns comentários sobre a tradução alemã de Peder Paars. Que esta tradução não capture tanto os olhos quanto o original dinamarquês não surpreende, pois escritos desse tipo perdem toda a sua virtude em roupas estrangeiras. O mesmo se aplica ao Hudibras inglês e a outros escritos da mesma natureza que, como resultado, não são traduzidos. Não culpo o trabalho do tradutor. Eu próprio não sou absolutamente competente para julgar a língua alemã. Eu direi apenas que poemas cômicos como esse não têm apelo fora de suas roupas domésticas, e é por isso que sempre me pronunciei contra a tradução deste trabalho.

Aqui encontramos a ideia do traje, querido por Voltaire, em um argumento relativístico cuja extrema consequência é a recusa da tradução. Mas Holberg ainda está falando de uma epopeia? Não é em nome da moral e dos costumes, mas sim no poder cômico do poema, que ele recusa a tradução. Se é, na tradução alemã (Heldergedicht) como no original dinamarquês

\footnotetext{
${ }^{41}$ Peder Paars ein komisches Hedengedicht. Leipzig: Franz Christian Mumme, 1750

42 HOLBERG, Ludvig. Epistola 447. Epistler [1754]. Disponível em : http://holbergsskrifter.dk. N.T. O autor do artigo apresentou versão em francês do trecho citado, na qual baseamos nossa versão em português.
} 
(poema heroico-comicum, heroisk-comisk poema), um poema heroico, os dois componentes genéricos parecem não ter a mesma importância.

Isso pode parecer ainda mais surpreendente, uma vez que o poema é literalmente costurado a partir de citações da Eneida e de outros textos da tradição épica, escritos nos holandeses dinamarqueses por Holberg e relatados pelo próprio autor (embora por através de complexa ficção editorial) em notas que acompanham o texto: "Ach, slip en kratig Vind, og havet for mig rør! (b)/ Incute vim ventis etc. Virg" ${ }^{43}$

O verso dinamarquês (“Ah, envie um vento forte e levante as ondas para mim!”44) Está explicitamente associado ao hipotexto virgiliano ("libera a força dos ventos ..."). Esse mecanismo é o da paródia, no sentido de Asconius, ou seja, nas palavras do padre Sallier, "I'application toute simple de quelques vers connus, ou d'une partie de ces vers" [a simples aplicação de alguns versos conhecidos ou parte desses versos] a uma nova situação ${ }^{45}$, e não parece ser incompatível com a tradução. Portanto, há algo mais, sem dúvida devido à ideia de Holberg da genialidade da língua dinamarquesa, que argumenta contra a tradução.

De qualquer forma, Holberg considera que o valor de sua epopeia depende do que é, e não do que poderia ou deveria ser: ele o escreve em reação a um sistema poético em que a forma precede o significado, e valoriza o aspecto mais contingente, que é a forma linguística (que era um moderno muito moderno como La Motte durante a briga de Homero). A combinação desses dois critérios o tornaria um modelo de definição em si, se fosse um poema puramente heroico: mas um poema heroico é necessariamente definido em relação a um cânone que ele desvia e que the fornece objetivo. Peder Paars não é uma proposição épica positiva, mas sim (de maneira bastante análoga ao Peri Bathous) um desvio particularmente poderoso das formas e ideias contemporâneas.

\section{Post rem: isto é uma epopeia}

A literatura polonesa da segunda metade do século XVIII é dominada pelo classicismo stanislaviano (klasycyzm stanisławowski). Boileau e Pope são leituras privilegiadas, e suas ideias, combinadas com as de Aristóteles e Horácio, alimentam o Sztuka rymotwórcza (Poetic Art, 1788), de Franciszek Xawery Dmochowski (1762-1808). A epopeia, como na Poetic Art de Boileau, é tratada no terceiro canto deste poema didático e retoma amplamente as palavras do

\footnotetext{
${ }^{43}$ HOLBERG, Ludvig. Peder Paars [1721], I, i, v. 163. Disponível em: http://holbergsskrifter.dk.

44 N.T. Versão em português baseadas na versão em francês apresentada pelo autor do artigo.

45 SALLIER, Claude. Discours sur l'origine et le caractère de la parodie. In : Mémoires de littérature tirés des registres de l'Académie des Inscriptions et Belles-lettres. Paris : Imprimerie Royale, 1733, t. XVII, p. 400 ; cf. o comentário de Asconius a Cícero. In : Verrem actio prima, $X$.
} 
poeta francês: em suma, parece que esse classicismo do final do século subscreve uma definição ante rem do gênero épico.

Esse é sem dúvida o caso de Dmochowski, mas as coisas ficam complicadas quando passamos por O Rymotwórstwie i rymotwórcach [Sobre poesia e poetas], o trabalho teórico póstumo do poeta épico mais importante do período, Ignacy Krasicki (1735). -1801). É uma leitura rápida do capítulo que esse herdeiro dos debates estéticos do século XVIII dedica ao épico que focalizaremos aqui.

Gostaríamos de argumentar aqui que a definição proposta por Krasicki, se trai um apego profundo à ideia normativa (Krasicki é afinal colega íntimo de Dmochowski) e parece em vários aspectos (notadamente a forma do capítulo) se inspirar em Essai de Voltaire, é, em última análise, uma definição post rem, uma definição em que o investimento teórico (intenção) é limitado ao máximo em favor da acumulação de elementos.

É assim que o capítulo se abre: não com uma reflexão teórica geral sobre o épico, mas sobre uma arqueologia do gênero:

Rodzaj ten wierszy, ledwo nie spółczesnym pierwszemu nazwać można ; jak bowiem tamten z winnej czci najwyższej Istności, ten z szacunku, zadziwienia i wdzięczności pochodzit, i dotùd też ma pobudki. Bohaterskim się nazywa, ponieważ celem jego jest obwieszczać czyny pamięci godne znamienitych mężów. Równie jak w ćwiczonych, i w dzikich narodach pieśni takowe składane bywały. Prostota gminu, która się mało od dziczy różni, zachowała je u siebie, i dotad zachowuje w każdym prawie kraju : tak dalece, iż gdyby te dumy zebrane i ściśle roztrzqśnione były, może stad dziejopisowie, osobliwie w wydobyciu kraju każdego pierwiastków, wiele korzystać mogli. ${ }^{46}$

[Dificilmente é possível não apresentar esse gênero poético como contemporâneo do primeiro; como, de fato, o outro [ode, tratado no capítulo anterior], derivado da digna honraria prestada ao Ser Supremo, este deriva-se da estima, do espanto e do encanto, e é a isso que ele também convida. Ele é chamado de heroico porque seu objetivo é divulgar as ações dignas da memória de homens notáveis. Tais poemas foram compostos tanto entre as nações policiadas quanto entre os selvagens. A simplicidade do povo, que pouco difere da dos selvagens, os preservou ali e ainda os preserva em todos os tipos de países: é provável que, na medida em que esses cantos fossem coletados e discutidos com precisão, os historiadores pudessem muito disso, principalmente no que diz respeito às origens de cada país.]

A epopeia forma com a letra religiosa um díptico que se refere a sentimentos primordiais e apoia a comemoração dos atos da humanidade (quando a ode é responsável, de diferentes maneiras, pela comunicação com a divindade). Em vez de considerar os critérios que permitem o reconhecimento de gênero, Krasicki afirma desde o início sua universalidade: o gênero é aqui

\footnotetext{
${ }^{46}$ KRASICKI, Ignacy. O Rymotwórstwie i Rymotwórcach in Dzieła Ignacego Krasickiego. Edycja nowa i zupełna przez Franciszka Dmochowskiego. Warszawa : Gröll, 1802, t. III, p. 10. N.T. O autor do artigo apresenta versão em francês na qual nos baseamos para a versão em português.
} 
dado a serviço de um propósito antropológico mais amplo do que o objeto de construção discursiva. A epopeia também não é limitada, como ainda era o caso de Voltaire, às "nações educadas": a definição ecoa as reflexões antropológicas do século e dá à epopeia, acima de tudo, o valor documental cujos principais beneficiários são "historiadores [dziejopisowie]" e não críticos ou poetas.

Portanto, dificilmente ficaremos surpresos ao ver Ossian citado antes de Homero:

Na czele takowych pieśni kłaść można dumy Ossjana, ciqgłym wieków podaniem zachowane w Szkocji, i które niedawno zebrane i podane do wiadomości powszechnej, rozmaitościq, zwięzłościq i dzielnościq wyrazów swoich, zadziwiajq czytelników ${ }^{47}$

[Pode-se colocar à frente de poemas desse tipo os cantos de Ossian, preservadas na Escócia em constante passagem pelos séculos até os dias atuais, que, recentemente coletadas e trazidas ao conhecimento de todos, encantam seus leitores com a variedade, a concisão e ousadia de suas expressões.]

O tipo de charme que os cantos de Ossian exercem sobre o leitor contemporâneo se deve a um fascínio pela matéria humana bruta da qual eles se fazem testemunhas: e se o mesmo discurso primitivista pudesse ser realizado, a partir da querela, sobre os heróis Homero, ele sofreria das racionalizações retrospectivas às quais foi submetido.

O gesto crítico aqui é muito diferente do que vimos até agora: a afirmação da existência de gênero (nos tempos e lugares mais distantes) serve como evidência, mas dificilmente parece precisar ser comprovado. $\mathrm{O}$ conceito de regras aparece apenas no terceiro parágrafo:

Prawidła wiersza bohaterskiego w powszechności te sq : naprzód, iżby rzecz obwieszczajqcy wyrażał zadziwienie powieściq swojq ; iżby jednq osobę wziqł na cel pierwszy, i nad to najszczególniej się zastawiat, tak jak wystawuje Homer w lliadzie Achillesa, w Odysei Ulissa. Osoba, która za cel bierze, ma być godna uwielbienia osobliwego, i drugiej znamienitszej nad niq, iżby $w$ dziele nie było.

Nie zdaje się trzymać tego prawidła Wirgiliusz w Eneidzie, Tasso $w$ Jerozolimie, a co najnieprzystojniej, Milton w Raju utraconym, gdzie diabet pierwsze miejsce trzyma. ${ }^{48}$

[As regras dos poemas épicos são geralmente as seguintes: em primeiro lugar, ao tratar seu assunto, que se faça com que a narrativa leve ao maravilhamento; que se tome apenas uma pessoa como matéria e que se fale sobre isso em todos os detalhes, como Homero fez com Aquiles na llíada ou de Ulisses na Odisseia. A pessoa que tomamos como matéria deve ser digna de uma admiração particular, e não haverá na obra alguém mais notável que ela!

\footnotetext{
${ }^{47} \mathrm{Ibid}$. O autor do artigo apresenta versão em francês na qual nos baseamos para a versão em português.

${ }^{48}$ Op. cit., p. 10-11. O autor do artigo apresenta versão em francês na qual nos baseamos para a versão em português.
} 
Não parece que essas regras sejam seguidas por Virgílio na Eneida, por Tasso em Jerusalém, e o que é particularmente inaceitável, por Milton no Paraíso Perdido, em que o Diabo ocupa o primeiro lugar.]

O poema heroico é definido por seu herói: essa primeira regra é coerente com a definição antropológica do poema proposta na abertura do capítulo. O tratamento do herói está então sujeito a uma definição a priori: deve ser (a) o objeto único do poema, (b) tratado em todas as suas facetas e (c) incorporar valores positivos (pelo menos, levando em conta o primeiro parágrafo, em relação à sua comunidade de referência). O breve parágrafo seguinte lista as violações da regra de Virgílio, de Tasso [que não respeita (a) e, portanto, provavelmente também não (b), embora em escalas diferentes] e de Milton [que negligencia (c)]. Essa última ofensa é a mais grave, e é notável que ela se situa em um plano antropológico (ela afeta o valor comemorativo do poema) mais que poético (o tratamento do objeto).

Ainda mais notável é o tom neutro e prático desse parágrafo e a ausência de qualquer notação deôntica ou reserva genérica: obviamente, a existência de entorses tão graves não afeta o status de epopeia dos textos considerados. Daí duas soluções: ou a entorse desse critério não é proibitiva, ou o rótulo genérico de "poema épico" é atribuído a esses textos de maneira amplamente independente de sua conformidade com uma poética analítica. Tendo adquirido a importância do critério nas próprias palavras de Krasicki (é o primeiro e é constitutivo do título genérico), parece que se trata aqui de registrar na maioria dos graus de regularidade em comparação a um padrão tradicional, mas não decisivo, dentro de um corpus composto de critérios que se enquadram em outro campo que não o da poética.

Por que observar essas diferenças, se suas consequências são anedóticas? Sugerimos que essa é uma forma de nostalgia da poética normativa. O parágrafo a seguir é um exemplo:

Rytm ma być poważny, żywy, i tak rzecz opiewajqcy, iżby czytajacy zdawał się patrzeć na na to, co mu się przed oczyma stawia. Przenosi w tej mierze Homer nad następców swoich, i z niego najwłaściwiej wziq̨ pochop Horacjusz do pierwiastkowego sztuki swojej rymotworskiej wyrazu, iż równie malarstwu rymotwórstwo być powinno : ut pictura poesis erit. ${ }^{49}$

[O ritmo deve ser sério, animado e tornar o assunto tão lisonjeiro que, ao ler, é preciso ter a impressão de ver o que está diante de nossos olhos. Como chefe Homero prevalece sobre seus sucessores, e foi ele quem inspirou Horácio na máxima fundamental de sua arte poética, que a poesia deve ser semelhante à pintura: ut pictura Poesis erit.]

Pode parecer contraditório exigir que o ritmo do poema seja sério (poważny) e animado (żywy) ao mesmo tempo. A leitura mais simples é considerar que os dois qualificadores se

\footnotetext{
${ }^{49}$ Op. cit., p. 11 . O autor do artigo apresenta versão em francês na qual nos baseamos para a versão em português.
} 
aplicam em momentos diferentes e que esta é uma síntese dos conselhos de Boileau: "Soyez vif et pressé dans vos narrations. / Soyez riche et pompeux dans vos descriptions [Seja vivo e rápido em suas narrações. /Seja rico e pomposo em suas descrições] ${ }^{50}$.

De qualquer forma, Homero domina aqui o corpus - onde encontramos o julgamento de Pope: "Homer is universally allowed to have had the greatest Invention of any writer whatever" ${ }^{51}$ [Homero é universalmente autorizado a ter a maior Invenção de qualquer escritor de qualquer tempo] ", e de Homero o deslizamento é rápido em direção à tradição poética ocidental e à topografia horaciana. Em um parágrafo encontram-se assim concentradas as referências ao cânone épico (Homero) e à poética normativa (Horácio e Boileau).

A ideia da tecnologia clássica assume todo o seu significado aqui. É evidente que Krasicki, como Dmochowski, está ligado (provavelmente mais por conviç̧ão real do que por simples conformismo) aos instrumentos intelectuais da poética normativa; mas seu texto (pelo contrário, desta vez, ao de Dmochowski), atesta as dificuldades que ele experimenta em usá-los em novos objetos (ossianos, por exemplo) que reformaram radicalmente a maneira de definir o gênero épico. A poética krasickiana não mostra mais o espírito sistêmico que emergiu dos textos de Pope, mas definitivamente constitui uma "bricolagem" teórica", usando as mesmas ferramentas.

Encontraremos, sobre o critério da unidade de lugar, o mesmo funcionamento:

Jedność miejsca, lubo ściśle zachowana $w$ lliadze, w Odysei $i$ Eneidzie nie znajduje się: tamta bowiem Ulissesa podróże ta Eneasza z Azji przez Afrikę do Europy przeniesienie obwieszcza. Milton tam stawia osoby i rzeczy, gdzie go tylko rozbujana myśl unosi. Nie traci jednak szacunku swojego, gdy wielokrotne błędy żywościq wyrazów i opisań nagradza ${ }^{52}$

[A unidade de lugar, embora observada com precisão na llíada, não é encontrada na Odisseia e na Eneida: porque a primeira trata das jornadas de Ulisses, a segunda com a jornada de Enéias da Ásia para a Europa via África. Milton coloca seus personagens e objetos onde apenas seu pensamento exaltado o leva. Porém, não perde seu valor quando seus inúmeros erros são compensados pela vivacidade de seus truques e descrições.]

O estilo discutido acima salva Milton aqui, que, portanto, atende apenas a um dos três critérios discutidos (tratamento do herói, estilo e unidade do lugar), cada um dos quais é aparentemente uma condição suficiente, mas nunca necessária para o reconhecimento do gênero épico. Krasicki torna-se cada vez mais crítico (ou seja, leitor informado) e cada vez menos

\footnotetext{
${ }^{50}$ BOILEAU-DESPREAUX, Nicolas. Épîtres. Art poétique. Lutrin. Charles-Henri Boudhors (Ed.)., Paris : Les Belles Lettres, 1967, p. 103.

51 "Preface". In: POPE, Alexander (Trad.). The Iliad of Homer [1715]. Steven Shankman (Ed.)., London: Penguin, 1996, p. 3.

52 KRASICKI, Ignacy. O Rymotwórstwie i Rymotwórcach, op. cit., p. 11-12. O autor do artigo apresenta versão em francês na qual nos baseamos para a versão em português.
} 
poético (praticante de uma ciência da composição, que convidava seus leitores a adotar em relação às obras o ponto de vista genético do poeta em ação).

Najpierwszy, i co do czasu i co do wytworności, pisarz dzieł bohaterskich jest Homer. Dzieła jego prawidłem się stały dla następców, i mimo ich sławę, wartości i pierwszeństwa swojego ni tracq. Zdaje się, iż wysiliło się przyrodzenie na pierwszym wstępie, gdy tyle wieków następnych, jeszcze przewyższeniem Homera zaszczycić nie mogły. ${ }^{53}$

[O primeiro autor de obras heroicas, tanto no tempo como por suas realizações, é Homero. Suas obras se tornaram uma regra para seus sucessores e, apesar da glória desses últimos, não perderam nem seu valor nem sua preponderância. Parece que a natureza deu toda a sua força ao primeiro, e nos tantos séculos que se seguiram os outros não souberam se distinguir ultrapassando Homero.]

Aqui a natureza transcendente de Pope desaparece: se Homero tem o status de cânone, é basicamente por padrão. $O$ primitivismo homérico prevalece aqui sobre a ambição normativa.

O capítulo adota um formato muito próximo do Essai de Voltaire: Krasicki continua os exames de poetas individuais: Homero, Virgílio, Silius Italicus, Claudiano, Trissino, Dante, Tasso, Ariosto, Milton, Klopstock, Camões e Voltaire. Entre esses, alguns estão nas fronteiras de gênero. Quanto ao Punica de Silius Italicus: “c'est à peine si le souffle poétique se donne parfois à reconnaître et à sentir dans cet ouvrage; il faudrait ainsi plutôt l'appeler une histoire en vers" 54 [dificilmente se às vezes é dado o fôlego poético para reconhecer e sentir nessa obra; deveria ser assim chamada de história em verso] - o que implica que nenhum dos critérios acima é encontrado lá: portanto, não há razão suficiente para considerar o Punica como um épico. Quanto a Dante, ele destaca o critério quase etnológico que agora consagra um texto como epopeia:

Ściśle rzecz biorqc, dzieło Danta Aligerjusza do poematów heroicznych nie powinno. Że jednak jemu sława wzniesienia języka należy, a zaś $w$ dziele sq takie niektóre opisy, któreby $w$ tym rodzaju pisania mogły mieść miejsce, osadzać go gdzieindziej nie zdaje się. ${ }^{55}$

[Considerando o tema de perto, a obra de Dante Alighieri não deve ser computada entre poemas épicos. Porque, no entanto, pertence a ela a glória de ter ilustrado a língua italiana, e considerando que em sua obra há algumas descrições que poderiam ter seu lugar nesse gênero de escrituras, não parece aconselhável classificá-la de outro modo.]

(Aí se revela toda um destaque ao critério estilístico ao lado do critério nacional).

\footnotetext{
53 Op. cit., p. 12. N.T. O autor do artigo apresenta versão em francês na qual nos baseamos para a versão em português.

54 N. T. Sem referência.

55 Op. cit., p. 17-18. N. T. O autor do artigo apresenta versão em francês na qual nos baseamos para a versão em português.
} 
No final do capítulo, vem um breve desenvolvimento sobre o gênero herói-cômico (poema krotofilne). É claro que o debate está ativo desde Boileau; mas, como Holberg testemunha, a classificação de poemas herói-cômicos como propriamente épicos estava longe de se estabelecer em meados do século XVIII. Note-se que os critérios enfraquecidos de Krasicki não são incompatíveis com a admissão de Secchia, Le Lutrin ou The Rape of the Lock no corpus épico; e pode-se supor que a importância estatística desse subgênero no século XVIII exigisse que uma teoria post rem o explicasse, o que é relativamente simples ${ }^{56}$.

\section{Conclusão}

Tiraremos, dessas rápidas leituras da metodologia poética do século XVIII, duas conclusões que podem parecer opostas, mas que são de interesse primário para nossa própria maneira de teorizar o gênero épico e de receber discursos críticos de épocas distantes.

A primeira é que parece resolutamente ilusório resistir à ideia de que, no século XVIII, está ocorrendo uma forma de transição teórica que leva a massa de críticos da poética normativa mais realista (segundo a qual categorias de gênero existem mais ou menos independentemente de seu conteúdo) a uma crítica cada vez mais posteriorista (na qual o crítico constata o conteúdo do gênero antes de tentar estabelecer os critérios). Essa alteração da relação com a categorização está associada a uma mudança de relação com o trabalho poético: do esforço para se adaptar a um modelo mais ou menos abstrato e exigente, sobre o qual o cânone fornece uma visão geral no primeiro caso, ao surgimento de uma individualidade excepcional que assume a singularidade nacional no segundo. Nesse sentido, vemos claramente a concepção nacional e romântica da poesia narrativa, que críticos alemães como Herder também começaram a expressar antes mesmo de Krasicki propor sua revisão da poética.

A segunda conclusão é que essa mudança teórica não constitui uma mudança radical de paradigma. As definições ante rem alimentam-se, no século XVIII, do espírito empírico, e uma definição in re, como a de Voltaire, reconstrói critérios universais. A mais perigosa, para a tecnologia clássica, é finalmente a definição post rem de Krasicki, porque é a mais fraca no nível poético (da intenção) e porque possui o maior corpus (a maior extensão) a coletar. Os gêneros devem corresponder a alguma coisa, e se são cada vez menos apreciados em termos de critérios poéticos, é porque outros (etnográficos) os substituíram mais ou menos discretamente (o papel de Ossian é determinante). No entanto, Krasicki deseja, sem dúvida, salvar a noção de regularidade, e sua obra como crítico (que não aborda apenas a epopeia) testemunha isso

\footnotetext{
${ }^{56}$ Notemos que para um defensor de poéticas normativas como Batteux, Le Lutrin é uma verdadeira epopeia e, como tal, uma comparação perfeitamente aceitável com Henriade; cf. BATTEAUX, Charles. Parallèle, op. cit.
} 
abundantemente, assim como sua obra como poeta épico. Seria muito artificial tentar formalizar seu pensamento como um sistema condescendente em considerar o apego de alguém à tecnologia clássica como simplesmente anacrônico.

A disciplina poética, como a era clássica a moldou, alimenta-se muito mais de disfunções do pensamento do que de sua coerência. A poética épica de Krasicki é um exemplo de uma tentativa sincera de síntese entre a mudança de perspectiva da antiguidade (clássica ou nórdica), a produção épica do século XVIII e a evolução do sentimento estético na Europa. Ao se obstinar, embora timidamente, a transmitir critérios abstratos de julgamento crítico, Krasicki impõe às obras um contexto que é um obstáculo ao maravilhamento incondicional, e possivelmente à melhor maneira de fazer da epopeia um denominador comum da humanidade.

\section{Referências bibliográficas}

Lettres édifiantes et curieuses, écrites des Missions étrangères par quelques missionnaires de la Compagnie de Jésus. Paris ; p. G. Le Mercier, t. XXVI, 1743.

BARBAZAN, Étienne (Éd.). Fabliaux et contes des poetes françois des XIII, XIV et XV ${ }^{\text {es }}$ Siécles, Tirés des meilleurs Auteurs. Paris : Vincent, 1761.

BATTEUX, Charles. Parallèle de la Henriade et du Lutrin. Paris : s. n., 1748.

BATTEUX, Charles. Cours de Belles-lettres, ou principes de la littérature. Nouvelle édition. Paris : Desaint et Saillant, 1753, 4 t.

BATTEUX, Charles. Les Quatre Poëtiques. Paris : Saillant, Nyon, Desaint, "Avant-propos", 1771, 2 t.

BOILEAU-DESPREAUX, Nicolas. Épîtres. Art poétique. Lutrin. Éd. Charles-Henri Boudhors. Paris : Les Belles Lettres, 1967.

CHARLES, Michel. L'Arbre et la Source. Paris : Seuil, “Poétique”,1985.

CHARLES, Michel. Introduction à l'étude des textes. Paris : Seuil, “Poétique”, 1995.

DACIER, Anne (Trad.). L'lliade d'Homère, traduite en françois, avec des remarques, par Madame Dacier. Paris, Rigaud, 1711, 3 vol.

ESCOLA, Marc ; RABAU, Sophie (Dir.). Théorie littéraire et textes possibles. La Lecture littéraire. Paris : Klincksieck, 2005.

ESCOLA, Marc (Dir.). Théorie des textes possible. Amsterdam : Rodopi, 2012.

GARNCARZYK, Dimitri. Comment peut-on être classique ? Les classicismes français et stanislavien entre histoire littéraire et poétique. In : Annales de l'Académie polonaise de sciences - Centre scientifique à Paris, $n^{\circ} 18$, Paris, Académie polonaise des sciences, décembre 2016, en ligne :

http://paris.pan.pl/fr/images/stories/pliki/PDF/Roczniki/R18/Annales\%2018\%20cz-2_105116.pdf.

HAZARD, Paul. La Crise de la conscience européenne [1935]. Paris : Le livre de Poche, 1994.

HOLBERG, Ludvig. Verke. holbergsskrifter.dk.

HOUDAR DE LA MOTTE, Antoine. Réflexions sur la critique. Paris : Du Puis, 1715. 
HOUDAR DE LA MOTTE, Antoine (Trad.). L'Iliade. Poëme. Avec un discours sur Homère. Par Monsieur de la Motte, de l'Académie Françoise. Paris, Grégoire Dupuis, 1714.

JAUSS, Hans Robert. Littérature médiévale et théorie des genres. Trad. Éliane Kaufholz. In : GENETTE, Gérard ; TODOROV, Tzvetan (Éd.). Théorie des genres. Paris : Éditions du Seuil, "Points essais", 1996, p. 37-71.

KRASICKI, Ignacy. Dzieła Ignacego Krasickiego. Edycja nowa i zupełna przez Franciszka Dmochowskiego. Warszawa, [Gröll], 1802, t. III.

PAIGE, Nicholas D. Before Fiction. The Ancient Regime of the Novel. Pittsburgh: University of Pennsylvania Press, 2011.

POPE, Alexander (Trad.). The Iliad of Homer [1715]. Éd. Steven Shankman. London: Penguin, 1996.

POPE, Alexander. The Major Works. Éd. Pat Rogers, Oxford: OUP, "Oxford World's Classics", 2008.

SALLIER, Claude. Discours sur l'origine et le caractère de la parodie. In : Mémoires de littérature tirés des registres de l'Académie des Inscriptions et Belles-lettres. Paris : Imprimerie Royale, t. XVII, 1733.

SCALIGER, Julius Cæsar. Poetices libri VII, [Genève], apud Petrum Santandreanum, 1594.

VOLTAIRE. The Complete Works of Voltaire. Oxford: Voltaire Foundation, t. 3B. 